\title{
Growth rate control of protein and nucleic acid content in Streptomyces coelicolor A3(2) and Escherichia coli B/r
}

\author{
Neelam Shahab, Fiona Flett, Stephen G. Oliver and Philip R. Butler \\ Author for correspondence: Philip R. Butler. Tel: +44 1612004226 . Fax: +44 1612360409. \\ e-mail: p.butler@umist.ac.uk
}

Department of Biochemistry and Applied Molecular Biology, University of Manchester Institute of Science and Technology, PO Box 88, Manchester M60 1QD, UK

\begin{abstract}
Escherichia coli possesses regulatory mechanisms that coordinate cell growth with the synthesis of essential macromolecules (protein, RNA and DNA). While fundamental differences have been identified in the growth habit and chromosome structure of $E$. coli and Streptomyces, little is known about these regulatory mechanisms in filamentous bacteria. This paper reports on the relationship between the macromolecule content of 5 . coelicolor $A 3(2)$ and its specific growth rate. The protein, RNA and DNA contents (g per $100 \mathrm{~g}$ biomass) of $S$. coelicolor A3(2) grown in steady-state continuous culture over a range of specific growth rates $\left(0.025-0.3 h^{-1}\right)$ were $31-45,10-22$ and $3.5-4.5 \%(w / w)$, respectively. This composition is qualitatively similar to that of other microorganisms. Changes in the macromolecular content of S. coelicolor A3(2) and $E$. coli B/r with specific growth rate appear to be essentially similar. However, the data indicate that the RNA content of S. coelicolor A3(2), grown under the conditions used, exceeds that of $E$. coli grown at the same specific growth rate. The data also suggest that overlapping rounds of replication are not a feature of DNA synthesis in S. coelicolor A3(2). This may be a function of the organism's low maximum specific growth rate. Alternatively, it may be a consequence of regulatory mechanisms which act to inhibit the initiation of DNA synthesis in a linear chromosome which is already undergoing replication.
\end{abstract}

Keywords: Streptomyces coelicolor, Escherichia coli, continuous culture, macromolecular content, growth control

\section{INTRODUCTION}

Streptomyces coelicolor $\mathrm{A} 3(2)$ is an aerial-mycelium-producing actinomycete (Waksman \& Henrici, 1943) and as such is a Gram-positive, soil-dwelling filamentous prokaryote. Many Streptomyces species are very important industrially, being responsible for the production of many diverse pharmaceutically active secondary metabolites.

The mechanisms governing the regulation of secondary metabolism in streptomycetes have been the subject of much research (reviewed by Chater, 1992; Champness \& Chater, 1994; Chater \& Bibb, 1996). As a general rule, secondary metabolism appears to be promoted when conditions restrict growth (Demain et al., 1983; Vining, 1986), one or more nutrients becomes depleted or its

Abbreviations: $C+D$ period, period required to replicate and segregate chromosome; HGU, hyphal growth unit; $\mu$, specific growth rate; $\mu_{\max }$ maximum specific growth rate; $\mu_{r}$, relative specific growth rate $\left(\mu / \mu_{\max }\right)$. availability is reduced (reviewed by Demain, 1989; Martin, 1989; Shapiro, 1989), and/or when a transient metabolic imbalance occurs (Hobbs et al., 1992). Regulatory mechanisms that have been implicated in controlling secondary metabolism include the stringent response (Ochi, 1987; Strauch et al., 1991; Takano \& Bibb, 1994), and the synthesis of threshold levels of small, diffusible signal molecules (Horinouchi \& Beppu, 1992).

It appears that the regulation of secondary metabolism is complex. However, either a low specific growth rate and/or a change in this rate appears to be an underlying feature of the majority of factors which have been implicated in this regulation. To adjust for the cell's metabolic demands and to maintain its genetic and structural integrity, regulatory mechanisms that coordinate macromolecule (DNA, RNA and protein) synthesis with the specific growth rate are necessary. These mechanisms have been most studied in Escherichia coli (reviewed by Neidhardt et al., 1987). Little is known 
about how macromolecule synthesis and growth are coordinated in Streptomyces species.

Some fundamental differences in both growth habit and genome organization between $S$. coelicolor A3(2) and E. coli are apparent. While $E$. coli grows by binary fission, the cell cycle completing with a balanced division, $S$. coelicolor A3(2) grows by apical hyphal extension and branch formation (Prosser \& Tough, 1991), which essentially results in unequal cell division (Kretschmer, 1982). Based on pulsed-field gel electrophoresis, the size of the $S$. coelicolor $\mathrm{A} 3(2)$ chromosome has been estimated to be about $8 \mathrm{Mbp}$ (Kieser et al., 1992), approximately twice that of the E. coli chromosome (estimated to be $4.5 \mathrm{Mbp}$; Cole \& Saint Girons, 1994). Finally, recent evidence has indicated that the chromosomal DNA of Streptomyces species is linear (Leblond et al., 1993; Lin et al., 1993), which contrasts with the traditional view of a covalentlyclosed circular bacterial chromosome. Given these differences, and the fact that $S$. coelicolor and $E$. coli have evolved to accommodate quite different ecological niches, it is possible that the regulatory mechanisms coordinating macromolecule synthesis and growth differ in these two prokaryotes. Moreover, considering that the specific growth rate appears to be an important factor determining secondary metabolism, it is worthwhile to examine the nature of these regulatory mechanisms in $S$. coelicolor A3(2). In this paper, as the first step towards understanding how $S$. coelicolor A3(2) coordinates macromolecule synthesis with growth, we report on the relationship between macromolecule content and specific growth rate in this micro-organism.

\section{METHODS}

Strain. The original spore stock of Streptomyces coelicolor A3(2) strain 1147 (Hopwood, 1959) was found to be heterogeneous; five distinct colony morphologies and associated colours (red, dark red, blue, cream, and cream with red tinge) were noted on R5 solid medium. From colony hybridization experiments (to investigate plasmid content), a single red isolate considered most representative of the wild-type strain was chosen, cultured on mannitol-soya (MS) solid medium, and used throughout this study. This wild-type isolate was a prototroph, $\mathrm{SCP} 1^{+} \mathrm{SCP} 2^{+}$ and produced, under suitable conditions, the secondary metabolites actinorhodin, undecylprodigiosin and methylenomycin. The strain was not tested for the production of $\mathrm{A}$-factor or calcium-dependent-antibiotic. A spore stock of this isolate was prepared according to Hopwood et al. (1985), and stored at $-20{ }^{\circ} \mathrm{C}$; the isolate was also stored at $4{ }^{\circ} \mathrm{C}$ as single colonies on MS solid medium.

Media. MS agar had the following composition per litre; mannitol $20 \mathrm{~g}$, soya bean meal/flour $20 \mathrm{~g}$, Difco Bacto agar $16 \mathrm{~g}$, tap water to 11 . Regeneration medium (R5) and yeast extract-malt extract (YEME) medium were prepared according to Hopwood et al. (1985). A modified YEME medium (containing 100 instead of $340 \mathrm{~g}$ sucrose $\mathrm{l}^{-1}$ ) was used in continuous culture experiments. It was prepared by autoclaving glucose and sucrose separately from yeast extract, Bacto peptone and malt extract for $1 \mathrm{~h}$ at $121^{\circ} \mathrm{C}$ and combining the two mixtures aseptically when cool.

Growth conditions. Both solid and liquid cultures of $S$. coelicolor $\mathrm{A} 3(2)$ were grown at $30^{\circ} \mathrm{C}$. Small batch cultures were grown in flasks containing stainless steel springs $\left(12.7 \mathrm{~mm} \times 6\right.$ turns $^{-1}{ }^{-1}$; Alliance Spring $\mathrm{Co}$ ) to improve aeration and aid dispersed growth. Shake-flask cultures were incubated in an orbital incubator shaking at 200 r.p.m.

Twenty millilitres $(1 \%, v / v$, of the final culture volume) of a $48 \mathrm{~h}$ shake-flask culture in YEME was used as a seed inoculum in all continuous culture experiments. These were carried out in an LH2000 fermenter (LH Engineering) with a total capacity of 31 and a working volume of 21 . Oxygen-sufficient conditions were achieved by aeration at a rate of 0.5 v.v.m. $\left(1.01 \mathrm{~min}^{-1}\right)$. The aeration rate was maintained constant with a mass-flow valve. To prevent loss of culture volume via evaporation, the air outflow was passed through a water-cooled condenser. The temperature, monitored using a platinum thermocouple, was maintained at $30^{\circ} \mathrm{C}$ using a heating element and a water-cooled heat exchanger. The $\mathrm{pH}$ was monitored using a combined $\mathrm{pH}$ electrode and controlled at $7 \cdot 0 \pm 0 \cdot 1$ by automatic additions of $5 \mathrm{M} \mathrm{NaOH}$. Stirrer speed was 1000 r.p.m. Continuous culture was established by first growing a batch culture until mid- to late-exponential phase and then switching on medium inlet and outlet peristaltic pumps at the desired flow rates. The working culture volume was maintained at 21 by an overflow weir.

Sampling and storage of samples. During continuous culture experiments, at least three samples were collected from the fermenter over two to three retention times, once a steady-state had been achieved. A steady-state was assumed when a constant biomass concentration was attained, usually after four culture volumes of medium had passed through. At each sampling time, $15 \mathrm{ml}$ of the initial sample was discarded to remove accumulated cells in the sampling port. A suitable volume of sample was subsequently collected and immediately placed on ice. Samples $(10 \mathrm{ml})$ were pipetted into $50 \mathrm{ml}$ centrifuge tubes containing $5 \mathrm{ml}$ distilled water which had been previously frozen. The ice was allowed to thaw and the contents of the tube were centrifuged at 4500 r.p.m. for $5 \mathrm{~min}$. The supernatant was discarded and the pellet resuspended in an equal volume of icecold water and re-centrifuged for a further $5 \mathrm{~min}$. The washed pellet was then frozen rapidly in an ethanol/dry ice mixture and stored at $-20^{\circ} \mathrm{C}$. No significant difference was found in the macromolecule content of biomass analysed immediately after sampling and after storage for up to one month. Each sample was individually examined for macromolecule content. For any individual dilution rate, the mean macromolecule content was calculated from at least three samples.

Analytical methods. Biomass was determined as dry weight of washed cells. Individual samples were vacuum filtered onto preweighed Whatman filter discs $(\mathrm{GF} / \mathrm{C}, 4.7 \mathrm{~cm})$. Filters and biomass were washed at least five times, each time with $10 \mathrm{ml}$ distilled water. They were then dried to constant weight in a vacuum oven at $80^{\circ} \mathrm{C}$. The biomass dry weight was taken to be the difference in the two weights. A biomass dry weight measurement was made for each sample analysed for macromolecule content (see above, Sampling and storage of samples).

The Lowry method was used to determine the protein content of $S$. coelicolor A3(2). The procedure for extraction of nucleic acids was as described by Herbert et al. (1971). Total cellular DNA was determined by the method of Burton (1956). RNA was determined by the orcinol method (Herbert et al., 1971).

Calculations. Values for the macromolecular content of E. coli $\mathrm{B} / \mathrm{r}$, grown in batch cultures at $37^{\circ} \mathrm{C}$ for specific growth rates of $0.42-1.73 \mathrm{~h}^{-1}$, were reported by Bremer \& Dennis (1987). Values reported were expressed in units of amino acids per $\mathrm{OD}_{460}$, nucleotides per $\mathrm{OD}_{460}$ and genomes per $\mathrm{OD}_{460}$. To enable a comparison of these data with those for $S$. coelicolor A3(2) obtained in this work, it was necessary to recalculate the 
E. coli values so that they were expressed in units of $\mathrm{g}$ per $100 \mathrm{~g}$ dry weight. This was done assuming the following: the molecular masses for the average amino acid residue, average RNA nucleotide residue, and average base pair were $108 \mathrm{Da}$ (composition of E. coli protein taken from Spahr, 1962), $324 \mathrm{Da}$ (composition of E. coli stable RNA taken from Nierlich, 1972) and $618 \mathrm{Da}$ (for a GC content of $50 \mathrm{~mol} \%$ ), respectively. The E. coli genome size was taken to be $4.5 \mathrm{Mbp}$ (Cole \& Saint Girons, 1994).

Protein and DNA content as reported by Bremer \& Dennis (1987) were from the experimental work of Churchward $e t$ al. (1981), who used similar assays to those used in this work. RNA content was from Churchward et al. (1982). Bremer \& Dennis (1987) stated that values for macromolecule content were accurate to better than $10 \%$ and representative for the specific growth rate. In this work a standard error of the mean of better than $10 \%$ was achieved for all assays (mean standard error $=2 \cdot 43 \%$ ).

All errors were treated using the Gaussian law of error propagation (Weltner et al., 1986).

\section{RESULTS AND DISCUSSION}

\section{Factors determining the choice of culture conditions}

The specific growth rate of a culture $(\mu)$ may be varied by changing either the nature of nutrients or the concentration of the growth-rate-limiting substrate. Schaechter et al. (1958) first demonstrated that, in Salmonella typhimurium grown at a fixed temperature, the cellular content of DNA, RNA and protein depended only on the specific growth rate and not on the nutrient supplement in the culture medium. The dependence of macromolecular content on specific growth rate observed in $S$. typhimurium was subsequently also shown to exist in E. coli B/r (Churchward et al., 1981).

Continuous culture allows the experimenter to vary the specific growth rate of a micro-organism to values approaching its maximum specific growth rate $\left(\mu_{\max }\right)$. Theoretically, the specific growth rate is equal to the dilution rate at a steady-state. Moreover, cells growing at steady-state in continuous culture will, by definition, be in balanced growth, with all the physiological advantages associated with that state (Campbell, 1957). Continuous culture was chosen as the preferred method for varying the specific growth rate of $S$. coelicolor A3(2) in the study reported here.

Continuous culture is best performed in a chemically defined medium where the nature of the growth-ratelimiting substrate is known. However, due to the formation of large, densely packed pellets, the growth of $S$. coelicolor strains in submerged culture on such media is difficult to analyse and results in a potentially physiologically heterogeneous environment. By the addition of polymeric compounds (e.g. Junlon or polyethylene glycol), minimal media have been developed to reduce this problem (Hobbs et al., 1989). However, due to either interference with the assays employed or an inability to completely wash these compounds from biomass samples, thus making dry weight measurements unreliable (unpublished data), such media proved unsuitable. Although

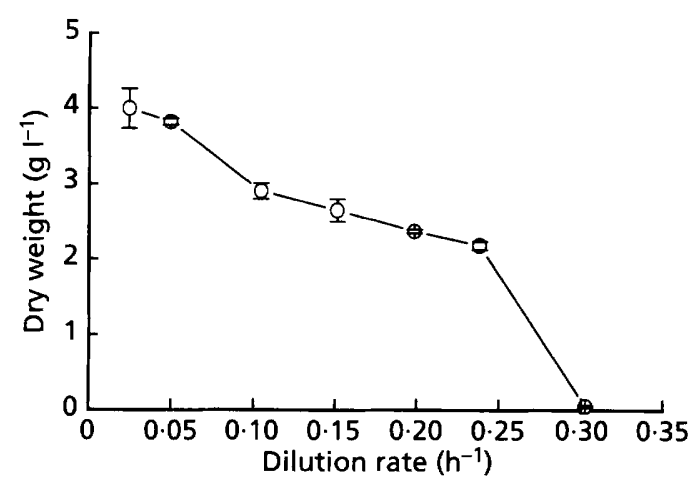

Fig. 1. Influence of dilution rate on biomass dry weight concentration of S. coelicolor A3(2). Each point $(O)$ represents the mean of five measurements. Bars represent the standard error.

not ideal, due to its high concentration of sucrose and thus potentially abnormal physiological properties, modified YEME (Hopwood et al., 1985) was chosen as a suitable growth medium for this study. This choice was governed both by the practical advantages YEME provided (i.e. a reasonably well-dispersed culture and reproducible assays) and the observations of Schaechter et al. (1958) that the cellular contents of DNA, RNA and protein depended only on the specific growth rate and not on the nature of the culture medium.

In this work, the $\mu_{\max }$ of $S$. coelicolor A3(2) was determined according to the method of Esener et al. (1981), from the wash-out kinetics of biomass in continuous culture, to be $0.34 \mathrm{~h}^{-1}$. Therefore, $S$. coelicolor A3(2) was grown at dilution rates ranging from 0.025 to $0.30 \mathrm{~h}^{-1}$. The $\mu_{\max }$ of $S$. coelicolor A3(2) is dependent on the nature of the growth medium and the strain. Values of $\mu_{\max }$ obtained from batch culture reported in the literature, include $0.021 \mathrm{~h}^{-1}$ (Ozergin-Ulgen \& Mavituna, 1993), 0.052-0.095 h-1 (Hobbs et al., 1990), 0.025-0.365 $\mathrm{h}^{-1}$ (Hodgson, 1982) and $0.30 \mathrm{~h}^{-1}$ (Strauch et al., 1991; Takano et al., 1992). It appears that the optimal $\mu_{\max }$ of $S$. coelicolor $\mathrm{A} 3(2)$ is in the range $0 \cdot 3-0.35 \mathrm{~h}^{-1}$.

To reduce the chances of mutant take-over due to genetic instability and selection, continuous culture was performed for the shortest time feasible, each dilution rate being examined as an independent fermentation. Biomass dry weight concentration was determined (see below) and samples were assayed for protein, RNA and DNA content.

\section{Variation of biomass concentration and cell/hyphal compartment size of S. coelicolor $A 3(2)$ with dilution rate}

Variation of biomass concentration. Biomass dry weight measurements were necessary to calculate the protein, RNA and DNA content of S. coelicolor A3(2) (content per cell mass; expressed as $\mathrm{g}$ macromolecule per $\mathrm{g}$ biomass dry weight). Fig. 1 shows the variation of biomass dry 
weight with dilution rate over the range $0 \cdot 025-0 \cdot 30 \mathrm{~h}^{-1}$. The biomass dry weight concentration decreased with increasing dilution rate, approaching about $0.05 \mathrm{~g} \mathrm{l}^{-1}$ at a dilution rate of $0.30 \mathrm{~h}^{-1}$. Since an undefined medium (modified YEME) was used to grow S. coelicolor A3(2), the nature and concentration of the growth-rate-limiting substrate in the inlet was not known. However, it is fair to assume that this concentration was the same for all dilution rates examined. Since no data were acquired about the nature, or residual concentration, of the growthrate-limiting substrate, no conclusions may be drawn on the cause of the relationship between biomass yield and dilution rate.

Estimation of cell/hyphal compartment size of $S$. coelicolor A3(2) by measurement of the hyphal growth unit. Changes in the macromolecular content (content per cell mass) of $E$. coli $\mathrm{B} / \mathrm{r}$ with specific growth rate may be explained by considering changes in the mean amount per cell (content per cell) and mass of an average cell (mass per cell) (see below). To gain a complete description of the dependence of macromolecular content on specific growth rate in $S$. coelicolor A3(2), both a measure of content per cell mass and mass of an average cell were deemed necessary. Measurement of the mean macromolecular content per cell mass proved relatively straightforward (given the growth conditions used; see Methods). However, measurements of the mass of an average cell are complicated by the fact that what constitutes a cell in filamentous micro-organisms is not clearly defined.

The hyphal ultrastructure of Streptomyces spp. is characterized by the formation of complete septa (Prosser \& Tough, 1991). The streptomycete mycelium is made up of three types of cell or hyphal compartment: apical, branched subapical, and unbranched subapical. To allow a complete analysis of the dependence of macromolecular content on specific growth rate in S. coelicolor A3(2), both the relative mean mass and the proportion of the total number of compartments that each cell type represents should be known. This information may be obtained by measuring the distance between septa, which have been located by staining. Our inability to reliably stain the septa of mycelial elements from $S$. coelicolor A3(2) grown in submerged culture prevented such an analysis (unpublished data). However, assuming that branched subapical cells have only one branch per hyphal compartment and that the proportion of unbranched subapical cells to other cell types is low (Kretschmer, 1982), the hyphal growth unit (HGU; defined as the total hyphal length divided by the number of apical tips) (Caldwell \& Trinci, 1973) may be considered as a measure of cell/hyphal compartment length.

Assuming that the hyphal diameter and the compartment density are approximately uniform along the hypha, and do not vary significantly with specific growth rate, the mean $\mathrm{HGU}$ is directly proportional to the mean cell mass. The HGU of $S$. coelicolor A3(2) grown under the conditions used in this study appeared not to vary significantly up to dilution rates of $0.20 \mathrm{~h}^{-1}$ (N. Shahab and others, unpublished). This suggests that the mass of an average $S$. coelicolor A3(2) cell also does not vary with specific growth rate. However, it must be stated that conclusions based on HGU are tentative, since measurements of this variable are restricted to mycelial elements of a simple structure which, in general, represented only a small proportion of the total population (unpublished). Also, it is not known whether the number of branches per hyphal compartment or the proportion of unbranched subapical cells changes with specific growth rate in $S$. coelicolor A3(2).

\section{Modulation of macromolecular content of $S$. coelicolor $\mathrm{A} 3(2)$ with specific growth rate and its comparison with $E$. coli $\mathrm{B} / \mathrm{r}$}

Data for the variation with specific growth rate of the macromolecular (protein, RNA and DNA) content of $S$. coelicolor $\mathrm{A} 3(2)$ (this work) and $E$. coli $\mathrm{B} / \mathrm{r}$ (recalculated from published data) are given in Table 1 . In $S$. coelicolor A3(2), protein, RNA and DNA represented 31-45, 10-22 and $3 \cdot 5-4.5 \%(\mathrm{w} / \mathrm{w})$ of the biomass, respectively. This composition is qualitatively similar to that of $E$. coli $\mathrm{B} / \mathrm{r}$, where protein represents the greatest proportion of the cell mass, followed by RNA, with DNA being the smallest fraction. In total, the macromolecules assayed in $S$. coelicolor A3(2) represented 56-63\% of the mycelial mass. This was significantly less than that observed in E. coli $\mathrm{B} / \mathrm{r}$ $(72-85 \%)$, the difference being, in part, due to a lower protein content in $S$. coelicolor A3(2).

Shahab et al. (1994) examined the RNA and DNA content of $S$. coelicolor A3(2) grown on cellophane membranes overlaid on solid minimal medium. Cultures grew at a specific growth rate of $0.06 \mathrm{~h}^{-1}$. RNA and DNA content were approximately 10 and $5 \%$ of the mycelial mass, respectively, during the active growth phase. This is in agreement with data presented in this paper for the macromolecular content of $S$. coelicolor A3(2) grown at a dilution rate of $0.05 \mathrm{~h}^{-1}$. This is as would be expected if the macromolecular content was determined by the specific growth rate and not by the nutritional status of the medium (Schaechter et al., 1958) or the growth habit.

Riesenberg \& Bergter (1979) examined the macromolecular composition of Streptomyces bygroscopicus IMET JA 6599 grown in both batch and continuous culture. The macromolecular composition they reported for $S$. bygroscopicus appears qualitatively similar to that of $S$. coelicolor A3(2), its protein content being, in general, significantly less than that observed in E. coli.

Table 1 shows that the highest specific growth rate at which measurements were made in $S$. coelicolor A3(2) $\left(0.30 \mathrm{~h}^{-1}\right)$ was lower than the lowest specific growth rate for which data have been reported on the macromolecular content of E. coli B/r $\left(0 \cdot 42 \mathrm{~h}^{-1}\right.$; Bremer \& Dennis, 1987). This made it impossible to compare the macromolecular content of these two micro-organisms at absolute values of the specific growth rate. To allow a meaningful comparison to be made between the two microorganisms, data for the macromolecular content of $S$. coelicolor $\mathrm{A} 3(2)$ and $E$. coli $\mathrm{B} / \mathrm{r}$ were plotted against the relative specific growth rate $\left(\mu_{\mathrm{r}}=\mu / \mu_{\max }\right)$ of each species 
Table 1. Macromolecular content of $E$. coli $\mathrm{B} / \mathrm{r}$ and S. coelicolor $\mathrm{A} 3(2)$

\begin{tabular}{|c|c|c|c|c|c|c|c|c|c|c|c|c|c|}
\hline & Units & \multicolumn{5}{|c|}{ E. coli $\mathbf{B} / \mathrm{r}^{*}$} & \multicolumn{7}{|c|}{ S. coelicolor A3(2) } \\
\hline & $\mu\left(\mathrm{h}^{-1}\right) \ldots$ & 0.420 & 0.690 & $1 \cdot 040$ & $1 \cdot 390$ & $1 \cdot 730$ & 0.024 & $0 \cdot 048$ & $0 \cdot 109$ & $0 \cdot 148$ & $0 \cdot 195$ & $0 \cdot 240$ & $0 \cdot 300$ \\
\hline Protein content & $\mathrm{g} \mathrm{g}^{-1}$ & 0.670 & 0.601 & 0.531 & 0.529 & 0.529 & 0.456 & 0.432 & 0.412 & 0.429 & 0.416 & 0.347 & $0 \cdot 313$ \\
\hline RNA content & $\mathrm{g} \mathrm{g}^{-1}$ & $0 \cdot 133$ & $0 \cdot 152$ & $0 \cdot 174$ & $0 \cdot 205$ & $0 \cdot 248$ & $0 \cdot 098$ & $0 \cdot 100$ & $0 \cdot 167$ & $0 \cdot 171$ & $0 \cdot 175$ & $0 \cdot 200$ & $0 \cdot 216$ \\
\hline DNA content & $\mathrm{g} \mathrm{g}^{-1}$ & $0 \cdot 042$ & $0 \cdot 029$ & $0 \cdot 022$ & $0 \cdot 019$ & $0 \cdot 017$ & $0 \cdot 044$ & $0 \cdot 042$ & $0 \cdot 036$ & $0 \cdot 033$ & 0.033 & $0 \cdot 036$ & $0 \cdot 035$ \\
\hline DNA content $\dagger$ & $10^{12}$ genomes $\mathrm{g}^{-1}$ & $9 \cdot 11$ & $6 \cdot 21$ & $4 \cdot 68$ & $4 \cdot 01$ & $3 \cdot 78$ & $5 \cdot 06$ & $4 \cdot 83$ & $4 \cdot 14$ & $3 \cdot 80$ & $3 \cdot 80$ & $4 \cdot 14$ & $4 \cdot 03$ \\
\hline $\begin{array}{l}\text { Protein per } \\
\text { genome }\end{array}$ & $10^{-13} \mathrm{~g} \mathrm{genome}^{-1}$ & $0 \cdot 74$ & 0.97 & $1 \cdot 13$ & $1 \cdot 32$ & $1 \cdot 40$ & 0.90 & 0.89 & 0.99 & $1 \cdot 13$ & $1 \cdot 10$ & $0 \cdot 84$ & $0 \cdot 78$ \\
\hline $\begin{array}{l}\text { RNA per } \\
\text { genome }\end{array}$ & $10^{-14}$ g genome $^{-1}$ & $1 \cdot 46$ & $2 \cdot 45$ & $3 \cdot 73$ & $5 \cdot 12$ & $6 \cdot 55$ & 1.94 & $2 \cdot 07$ & $4 \cdot 03$ & $4 \cdot 50$ & $4 \cdot 61$ & $4 \cdot 83$ & $5 \cdot 36$ \\
\hline
\end{tabular}

* Data for the macromolecular content for E. coli B/r were taken from Bremer \& Dennis (1987), recalculated as described in Methods.

$\dagger$ The molecular masses of the E. coli B/r and S. coelicolor A3(2) genomes were taken to be $2 \cdot 41 \times 10^{9}$ and $5 \cdot 2 \times 10^{9} \mathrm{Da}$, respectively. It was assumed that E. coli B/r has a genome size of $4.5 \mathrm{Mb}$ (Cole \& Saint Girons, 1994), and that S. coelicolor has a GC content of 70 mol \% (Gladek \& Zakrzewska, 1984; Usdin et al., 1984) and a genome size of about 8.0 Mb (Kieser et al., 1992; Leblond et al., 1993). The molecular masses of the $\mathrm{A}-\mathrm{T}$ and $\mathrm{G}-\mathrm{C}$ base pairs were taken to be 653 and $654 \mathrm{Da}$, respectively.

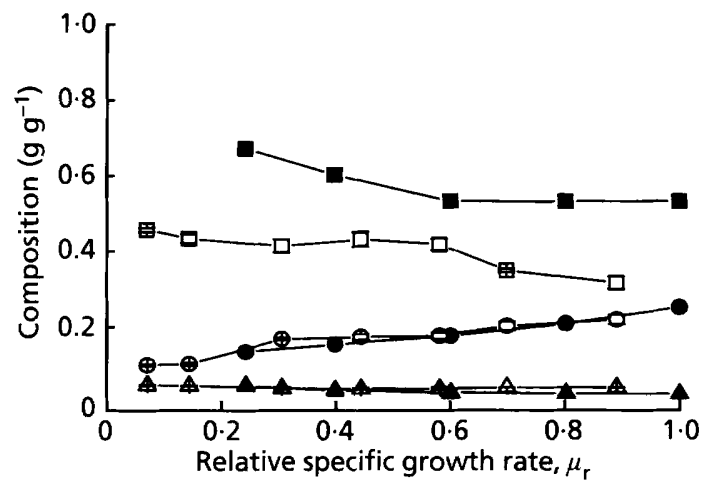

Fig. 2. Comparison of the dependence of macromolecular content on relative specific growth rate in $S$. coelicolor $A 3(2)$ and $E$. coli $B / r$. Protein $(\square, \boldsymbol{\square})$, RNA $(O, \boldsymbol{\theta})$ and DNA $(\triangle, \boldsymbol{\Delta})$ contents of S. coelicolor $\mathrm{A} 3(2)$ (open symbois) and of $E$. coli $\mathrm{B} / \mathrm{r}$ (filled symbols) are plotted against relative specific growth rate, $\mu_{\mathrm{r}}$. Data for the macromolecular content of S. coelicolor A3(2) are the means of at least three measurements; bars indicate the standard error. Data for $E$. coli $\mathrm{B} / \mathrm{r}$ are derived from Bremer $\&$ Dennis (1987). $\mu_{\mathrm{r}}$ was determined assuming $\mu_{\max }$ for $S$. coelicolor $\mathrm{A} 3(2)$ and $E$. coli $\mathrm{B} / \mathrm{r}$ to be 0.34 and $1.73 \mathrm{~h}^{-1}$, respectively.

(Fig. 2). The protein content of $S$. coelicolor A3(2) decreased with increasing specific growth rate. In $E$. coli $\mathrm{B} / \mathrm{r}$, protein content decreased up to a $\mu_{\mathrm{r}}$ of about 0.6 , above which it remained constant. Most strikingly, the RNA content of $S$. coelicolor $\mathrm{A} 3(2)$ and $E$. coli $\mathrm{B} / \mathrm{r}$ varied in an almost identical way, increasing proportionately with specific growth rate. The DNA content of both $S$. coelicolor $\mathrm{A} 3(2)$ and $E$. coli $\mathrm{B} / \mathrm{r}$ decreased with increasing specific growth rate.

In $E$. coli $\mathrm{B} / \mathrm{r}$, the protein and RNA content per cell increase with specific growth rate (Bremer \& Dennis, 1987). This reflects the increase in the cell's demands for these components at high specific growth rates and results in an increase in the average mass of a cell. Also, at high specific growth rates, the DNA content per cell increases with specific growth rate as a result of overlapping rounds of DNA replication. However, the DNA content per cell mass decreases because the average mass of a cell increases faster than the mass of DNA in the cell. The proportion of the cell's mass represented by protein remains approximately constant since the mass of protein per cell increases in direct proportion with the average mass of the cell. In contrast, the RNA content per cell mass increases with specific growth rate, because the RNA portion increases faster than the average cell mass.

Trends in the proportions of protein, RNA and DNA per cell mass in $S$. coelicolor A3(2) appear to be similar to those observed in E. coli B/r. However, since the HGU (and thus hyphal compartment size, accepting the above-stated assumptions) appears approximately constant up to a relative specific growth rate of about 0.7 (N. Shahab and others, unpublished), it appears that changes in the proportions of each macromolecule in $S$. coelicolor A3(2) probably do not arise from an overall increase in cell size.

\section{Indicators of the coordination of macromolecular synthesis and growth in S. coelicolor A3(2) and E. coli $\mathrm{B} / \mathrm{r}$}

Coordination of RNA synthesis with growth. The rate of synthesis of ribosomes in $E$. coli $\mathrm{B} / \mathrm{r}$ is coordinated with growth (reviewed by Jinks-Robertson \& Nomura, 1987). At high specific growth rates, rRNA represents the greatest single portion of the cellular RNA content. The suggestion that changes in the demand for protein synthesis are met by changes in the number of ribosomes, and not by changes in the catalytic activity of individual ribosomes, has been made to explain the observed proportionality between RNA per genome and specific growth rate in E. coli (Maaløe, 1969). 


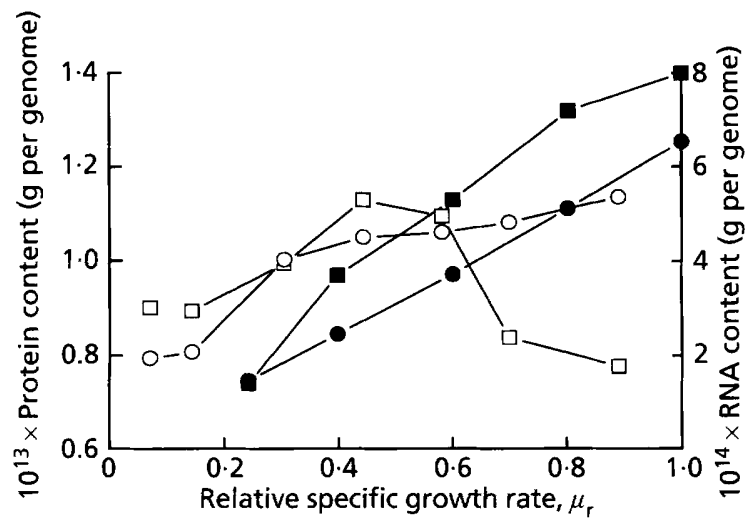

Fig. 3. Comparison of the dependence of protein and RNA per genome on relative specific growth rate in $S$. coelicolor $A 3(2)$ and E. coli B/r. Protein $(\square, \square)$ and RNA $(O, \bullet)$ per genome of $S$. coelicolor $A 3(2)$ (open symbols) and of $E$. coli $B / r$ (filled symbols) are plotted against relative specific growth rate, $\mu_{\text {. }}$. Data for the macromolecular content of $S$. coelicolor $A 3(2)$ are the means of at least three measurements; bars indicate the standard error. Data for $E$. coli $\mathrm{B} / \mathrm{r}$ are derived from Bremer \& Dennis (1987). $\mu_{\mathrm{r}}$ was determined assuming $\mu_{\max }$ for S. coelicolor $A 3(2)$ and $E$. coli $B / r$ to be 0.34 and $1.73 \mathrm{~h}^{-1}$, respectively.

The linear relationship between RNA content per genome and specific growth rate observed for $S$. coelicolor A3(2) (Fig. 3) suggests that, as with E. coli $\mathrm{B} / \mathrm{r}$, the demands of growth for protein synthesis in this micro-organism are met by changes in the number of ribosomes. However, it should be noted that the maximum specific growth rate of $S$. coelicolor $\mathrm{A} 3(2)$ is five times less than that of $E$. coli $\mathrm{B} / \mathrm{r}$. Thus, it might be argued that the demand for protein synthesis is considerably less in $S$. coelicolor A3(2). Assuming that the observed RNA content is mostly rRNA, and that ribosome structure is similar in the two organisms, the apparently higher RNA content of $S$. coelicolor A3(2) hyphae might be due to a low maximum specific ribosome activity, ribosomes operating submaximally, a higher proportion of ribosomes being present in an inactive form, and/or a higher turnover rate of rRNA. A relatively high ribosomal content may have evolved in streptomycetes to support the high proportion of extracellular protein synthesized by these organisms as an adaptation to growth on solid substrata (Shahab et al., 1994).

Coordination of DNA synthesis with growth. Taking into account the differences in size and GC content of the $S$. coelicolor $\mathrm{A} 3(2)$ and $E$. coli $\mathrm{B} / \mathrm{r}$ genomes, the protein content per genome and number of genomes per cell mass were calculated (Table 1). 'These data are plotted against $\mu_{\mathrm{r}}$ in Figs 3 and 4 . The dependence of the number of genomes per cell mass on specific growth rate was far greater in $E$. coli $\mathrm{B} / \mathrm{r}$ than in $S$. coelicolor A3(2) (Fig. 4). However, it is of interest that the concentration of genomes in the two organisms approaches approximately the same value, about $4 \times 10^{12}$ genomes $\mathrm{g}^{-1}$, when they are growing at their maximum specific rates. Values for

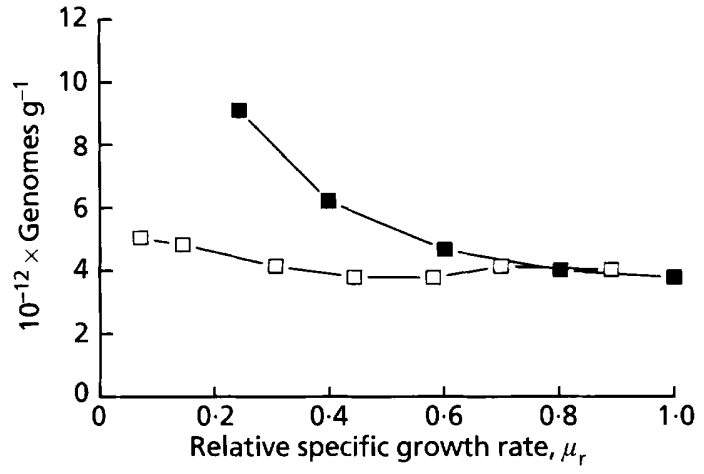

Fig. 4. Comparison of the dependence of number of genomes per cell mass on relative specific growth rate in $S$. coelicolor $A 3(2)$ and $E$. coli $B / r$. Number of genomes of $S$. coelicolor $A 3(2)$ $(\square)$ and of $E$. coli $B / r(\square)$ are plotted against relative specific growth rate, $\mu_{\mathrm{r}}$. Data for the macromolecular content of $S$. coelicolor $\mathrm{A} 3(2)$ are the means of at least three measurements. Data for $E$. coli B/r are derived from Bremer \& Dennis (1987). $\mu_{\mathrm{r}}$ was determined assuming $\mu_{\max }$ for $S$. coelicolor $\mathrm{A} 3(2)$ and $E$. coli $\mathrm{B} / \mathrm{r}$ to be 0.34 and $1.73 \mathrm{~h}^{-1}$, respectively.

protein per genome in $S$. coelicolor A3(2) were of a similar magnitude to those reported for $E$. coli $\mathrm{B} / \mathrm{r}$ (Table 1 ) but appeared to vary independently of the specific growth rate (Fig. 3).

In $E$. coli $\mathrm{B} / \mathrm{r}$, the rate of $\mathrm{DNA}$ replication is controlled not by the rate of chain elongation, but by the rate of initiation from the origin of replication, oriC. Growth at doubling times below the minimum $C+D$ period (the time required to replicate and segregate the chromosome) requires overlapping rounds of replication and results in the presence of partially replicated chromosomes at cell division. Thus the number of origins per genome increases with specific growth rate. Given this and the fact that the protein content per origin is relatively constant (reviewed by von Meyenburg \& Hansen, 1987; Bremer \& Churchward, 1991; Zyskind \& Smith, 1992), the protein content per genome must increase proportionally with the number of origins per genome. Thus, in $E$. coli $\mathrm{B} / \mathrm{r}$ growing at short doubling times, protein content per genome increases with specific growth rate (Fig. 3). At the doubling times at which $S$. coelicolor A3(2) grows this appears not to be the case (Fig. 3), implying that the number of origins per genome does not change significantly with specific growth rate.

Based on measurements of HGU, estimates of the mean size of $S$. coelicolor A3(2) cells indicate that cell size does not vary appreciably below specific growth rates of about $0.25 \mathrm{~h}^{-1}$ (N. Shahab and others, unpublished). Changes in the size of $E$. coli $\mathrm{B} / \mathrm{r}$ cells are most significant when the doubling time is less than the minimum $\mathrm{C}+\mathrm{D}$ period of 60 min (Bremer \& Dennis, 1987). Estimates of the C+D period in streptomycetes are rare. Miguélez et al. (1988) reported a $C$ period for $S$. antibioticus of $90 \mathrm{~min}$ but did not indicate at what specific growth rate this was measured. The doubling times of $S$. coelicolor A3(2) in our experi- 
ments ranged from 140 to $1730 \mathrm{~min}$. Based on the observation that the number of genomes per cell mass is relatively constant (Fig. 4) and assuming that the mean mass of a $S$. coelicolor A3(2) cell does not change with specific growth rate, the number of genomes per cell should be constant. If this is the case it would indicate that, under the conditions used, the doubling time is larger than the $C+D$ period and that overlapping rounds of DNA replication are not necessary for duplication of the $S$. coelicolor A3(2) chromosome.

The absence of overlapping rounds of DNA replication in $S$. coelicolor A3(2) may simply be a consequence of this organism's low maximum specific growth rate (as compared with E. coli). An alternative explanation is that mechanisms coordinating DNA replication and growth in $S$. coelicolor A3(2) may act to prevent re-initiation of chromosome replication during an ongoing round. This certainly appears to be the case in eukaryotic cells, which normally replicate their DNA only once between mitoses, re-initiation within existing replication bubbles being blocked (reviewed by Li \& Deshaies, 1993; Coverly \& Laskey, 1994). Regulatory mechanisms that block the segregation of replicating DNA molecules have presumably evolved to compensate for difficulties associated with the duplication of large, structurally complex genomes. The presence of such mechanisms in $S$. coelicolor A3(2) would have to be reconciled with the existence of a dna A gene, DnaA boxes at oriC (Calcutt \& Schmidt, 1992; Calcutt, 1994) and a single principal origin of replication (Musialowski et al., 1994). Certainly a level of post-initiation control appears to exist in E. coli and Bacillus subtilis (Levine et al., 1991, 1995), and might also be active in $S$. coelicolor A3(2). If eukaryotic-like regulatory mechanisms operate in S. coelicolor A3(2), the rate of DNA replication might be a significant determinant of the maximum specific growth rate of this organism. This would contrast with $E$. coli, where the maximum specific growth rate is determined mainly by the metabolic flux of substrates through primary and intermediary metabolism (Jensen \& Pederson, 1990; Marr, 1991).

\section{Conclusions}

Qualitatively, modulation of macromolecular content by specific growth rate in $S$. coelicolor $A 3(2)$ appears to be similar to that of $E$. coli $\mathrm{B} / \mathrm{r}$ in the following respects: (i) the majority of the biomass is made up of macromolecules, with protein representing the largest portion, followed by RNA, and DNA being the smallest; (ii) the relative proportions of the macromolecules changes with specific growth rate, the protein concentration decreasing, RNA concentration increasing and DNA concentration decreasing with an increase in the specific growth rate; (iii) the greatest relative change with specific growth rate is observed in the RNA portion.

The most striking differences between $S$, coelicolor A3(2), under the culture conditions used in this study, and $E$. coli $\mathrm{B} / \mathrm{r}$ are that the RNA content of $S$, coelicolor $\mathrm{A} 3(2)$ exceeds that of $E$. coli $\mathrm{B} / \mathrm{r}$ at the same specific growth rate, and S. coelicolor $\mathrm{A} 3(2)$ does not require or lacks the capability to generate overlapping rounds of DNA synthesis to replicate its genome.

\section{ACKNOWLEDGEMENTS}

N.S. acknowledges the financial support of the Malaysian government and the Standards and Industrial Research Institute of Malaysia (SIRIM). The authors gratefully acknowledge comments and criticisms from their colleagues Dr P. G. Lane and Dr D. C. J. Gardner.

\section{REFERENCES}

Bremer, H. \& Churchward, G. (1991). Control of cyclic chromosome-replication in Escbericbia coli. Microbiol Rev 55, 459-475.

Bremer, H. \& Dennis, P. P. (1987). Modulation of chemical composition and other parameters of the cell by growth rate. In Escherichia coli and Salmonella typhimurium: Cellular and Molecular Biology, pp. 1527-1542. Edited by F. C. Niedhardt, J. L. Ingraham, K. Brooks Low, B. Magasanik, M. Schaechter \& H. E. Umbarger. Washington, DC: American Society for Microbiology.

Burton, K. (1956). A study of the conditions and mechanisms of the diphenylamine reaction for colorimetric estimation of deoxyribonucleic acid. Biochem J 62, 315-322.

Calcutt, M. J. (1994). Gene organization in the dna $A-$ gyr $A$ region of the Streptomyces coelicolor chromosome. Gene 151, 23-28.

Calcutt, M. J. \& Schmidt, F. J. (1992). Conserved gene arrangement in the origin region of the Streptomyces coelicolor chromosome. J Bacteriol 174, 3220-3226.

Caldwell, I. Y. \& Trinci, A. P. J. (1973). The growth unit of the mould Geotrichum candidum. Arch Microbiol 88, 1-10.

Campbell, A. (1957). Synchronization of cell division. Bacteriol Rev 21, 263.

Champness, W. C. \& Chater, K. F. (1994). Regulation and integration of antibiotic production and morphological differentiation in Streptomyces species. In Regulation of Bacterial Differentiation, pp. 61-93. Edited by P. Piggot, C. P. Moran \& P. Youngman. Washington, DC: American Society for Microbiology.

Chater, K. F. (1992). Genetic regulation of secondary metabolic pathways in Streptomyces. In Secondary Metabolites: Their Function and Evolution (Ciba Foundation Symposium 171), pp. 144-162. Edited by D. J. Chadwick \& J. Whelan. Chichester: Wiley.

Chater, K. F. \& Bibb, M. J. (1996). Regulation of bacterial antibiotic production. In Biotechnology: Products of Secondary Metabolism, vol. 7. Edited by H. Kleinkauf \& H. von Dohren. Weinheim: VCH (in press).

Churchward, G., Estiva, E. \& Bremer, H. (1981). Growth tate dependent control of chromosome replication initiation in Escherichia coli. J Bacteriol 145, 1232-1238.

Churchward, G., Bremer, H. \& Young, R. (1982). Macromolecular composition of bacteria. J Theor Biol 94, 651-670.

Cole, S. T. \& Saint Girons, I. (1994). Bacterial genomics. FEMS Microbiol Rev 14, 139-160.

Coverly, D. \& Laskey, R. A. (1994). Regulation of eukaryotic DNA replication. Annu Rev Biochem 63, 745-776.

Demain, A. L. (1989). Carbon source regulation of idiolite biosynthesis in Actinomycetes. In Regulation of Secondary Metabolism, pp. 127-134. Edited by S. Shapiro. Boca Raton, FL: CRC Press.

Demain, A. L., Aharonowitz, Y. \& Martin, J. F. (1983). Metabolic control of secondary metabolite pathways. In Biochemistry and 
Genetic Regulation of Commercially Important Antibiotics, pp. 49-72. Edited by L. C. Vining. Reading, MA: Addison-Wesley.

Esener, A. A., Roels, J. A., Kossen, N. W. F. \& Roozenburg, J. W. H. (1981). Description of microbial growth behaviour during the wash-out phase; determination of the maximum specific growth rate. Eur J Appl Microbiol Biotechnol 13, 141-144.

Gladek, A. \& Zakrzewska, J. (1984). Genome size of Streptomyces. FEMS Microbiol Lett 24, 73-76.

Herbert, D., Phipps, P. J. \& Strange, R. E. (1971). Chemical analysis of microbial cells. Methods Microbiol 5B, 209-344.

Hobbs, G., Frazer, C. M., Gardner, D. C. J., Cullum, J. A. \& Oliver, S. G. (1989). Dispersed growth of Streptomyces in liquid culture. Appl Microbiol Biotechnol 31, 272-277.

Hobbs, G., Frazer, C. M., Gardner, D. C. J., Flett, F. \& Oliver, S. G. (1990). Pigmented antibiotic production by Streptomyces coelicolor A3(2) - kinetics and the influence of nutrients. J Gen Microbiol 136, 2291-2296.

Hobbs, G., Obanye, A. I. C., Petty, J., Mason, J. C., Barratt, E., Gardner, D. C. J., Flett, F., Smith, C. P., Broda, P. \& Oliver, S. G. (1992). An integrated approach to studying regulation of production of the antibiotic methylenomycin by Streptomyces coelicolor A3(2). J Bacteriol 174, 1487-1494.

Hodgson, D. A. (1982). Glucose repression of carbon source uptake and metabolism in Streptomyces coelicolor A3(2) and its perturbation in mutants resistant to 2-deoxyglucose. J Gen Microbiol 128, 2417-2430.

Hopwood, D. A. (1959). Linkage and the mechanism of recombination in Streptomyces coelicolor. Ann NY Acad Sci 81, 887-898.

Hopwood, D. A., Bibb, M. J., Chater, K. F., Kieser, T., Bruton, C. J., Kieser, H. M., Lydiate, D. J., Smith, C. P., Ward, J. M. \& Schrempf, H. (1985). Genetic Manipulation of Streptomyces: a Laboratory Manual. Norwich: John Innes Foundation.

Horinouchi, S. \& Beppu, T. (1992). Autoregulatory factors and communication in Actinomycetes. Annu Rev Microbiol 46, 377-398.

Jensen, K. F. \& Pederson, S. (1990). Metabolic growth rate control in Escherichia coli may be a consequence of subsaturation of the macromolecular biosynthetic apparatus with substrates and catalytic components. Microbiol Rev 54, 89-100.

Jinks-Robertson, S. \& Nomura, M. (1987). Ribosomes and tRNA. In Escherichia coli and Salmonella typhimurium: Cellular and Molecular Biology, pp. 797-806. Edited by F. C. Neidhardt, J. L. Ingraham, K. Brooks Low, B. Magasanik, M. Schaechter \& H. E. Umbarger. Washington, DC: American Society for Microbiology

Kieser, H. M., Kieser, T. \& Hopwood, D. A. (1992). A combined genetic and physical map of the Streptomyces coelicolor A3(2) chromosome. J Bacteriol 174, 5496-5507.

Kretschmer, S. (1982). Dependence of the mycelial growth pattern on the individual regulated cell cycle in Streptomyces granaticolor. Z Allg Mikrobiol 22, 335-347.

Leblond, P., Redenbach, M. \& Cullum, J. (1993). Physical map of the Streptomyces lividans 66 genome and comparison with that of the related strain. Streptomyces coelicolor A3(2). J Bacteriol 175, 3422-3429.

Levine, A., Vannier, F., Dehbi, M., Henckes, G. \& Seror, S. J. (1991). The stringent response blocks DNA replication outside the ori region in Bacillus subtilis and at the origin in Escherichia coli. J Mol Biol 219, 605-613.

Levine, A., Autret, S. \& Seror, S. J. (1995). A checkpoint involving RTP, the replication terminator protein, arrests replication downstream of the origin during the stringent response in Bacillus subtilis. Mol Microbiol 15, 287-295.
Li, J. J. \& Deshaies, R. J. (1993). Exercising self-restraint: discouraging illicit acts of $S$ and $M$ in eukaryotes. Cell 74, 223-226.

Lin, Y. S., Kiesre, H. M., Hopwood, D. A. \& Chen, C. W. (1993). The chromosomal DNA of Streptomyces lividans 66 is linear. Mol Microbiol 10, 923-933.

Maaløe, O. (1969). An analysis of bacterial growth. Dev Biol Suppl 3, 33-58.

Marr, A. G. (1991). Growth rate of Escherichia coli. Microbiol Rev 55, 316-333.

Martin, J. F. (1989). Molecular mechanisms for the control by phosphate of the biosynthesis of antibiotics and other secondary metabolites. In Regulation of Secondary Metabolism, pp. 213-238. Edited by S. Shapiro. Boca Raton, FL: CRC Press.

von Meyenburg, K. \& Hansen, F. G. (1987). Regulation of chromosome replication. In Escherichia coli and Salmonella typhimurium: Cellular and Molecular Biology, pp. 797-806. Edited by F. C. Neidhardt, J. L. Ingraham, K. Brooks Low, B. Magasanik, M. Schaechter \& H. E. Umbarger. Washington DC: American Society for Microbiology.

Miguélez, E. M., Martin, M. C., Manzanal, M. B. \& Hardisson, C. (1988). Hyphal growth in Streptomyces. In Biology of Actinomycetes '88, pp. 490-495. Edited by Y. Okami, T. Beppu \& H. Ugawara. Tokyo: Japan Scientific Societies Press.

Musialowski, M. S., Flett, F., Scott, G. B., Hobbs, G., Smith, C. P. \& Oliver, S. G. (1994). Functional evidence that the principal DNAreplication origin of the Streptomyces coelicolor chromosome is close to the dna A-gyrB region. J Bacteriol 176, 5123-5125.

Neidhardt, F. C., Ingraham, J. L., Brooks Low, K., Magasanik, B., Schaechter, M. \& Umbarger, H. E. (1987). Escherichia coli and Salmonella typhimurium: Cellular and Molecular Biology. Washington DC: American Society for Microbiology.

Nierlich, D. P. (1972). Regulation of ribonuleic acid synthesis in growing bacterial cells. II. Control over the composition of newly made RNA. J Mol Biol 72, 765-777.

Ochi, K. (1987). Metabolic initiation of differentiation and secondary metabolism by Streptomyces griseus: significance of the stringent response (ppGpp) and GTP content in relation to Afactor. J Bacteriol 169, 3608-3616.

Ozergin-Ulgen, K. \& Mavituna, F. (1993). Actinorhodin production by Streptomyces coelicolor $\mathrm{A} 3(2)$-kinetic-parameters related to growth, substrate uptake and production. Appl Microbiol Biotechnol 40, 457-462.

Prosser, J. I. \& Tough, A. J. (1991). Growth mechanisms and growth-kinetics of filamentous microorganisms. Crit Rev Biotechnol 10, 253-274.

Riesenberg, D. \& Bergter, F. (1979). Dependence of macromolecular composition and morphology of Streptomyces bygroscopicus on specific growth rate. $Z$ Allg Mikrobiol 19, 415-430.

Schaechter, E., Maaløe, O. \& Kjeldgaard, N. O. (1958). Dependence on medium and temperature of cell size and chemical composition during balanced growth of Salmonella typhimurium. J Gen Microbiol 19, 592-606.

Shahab, N., Kamaruddin, K., Platt, J., Butler, P. R., Oliver, S. G. \& Hobbs, G. (1994). Cell physiology and antibiotic production of Streptomyces coelicolor grown on solid medium. Biotechnol Lett 16, 1015-1020.

Shapiro, S. (1989). Nitrogen assimilation in Actinomycetes and the influence of nitrogen nutrition on Actinomycete secondary metabolism. In Regulation of Secondary Metabolism, pp. 135-212. Edited by S. Shapiro. Boca Raton, FL: CRC Press. 
Spahr, P. F. (1962). Amino acid composition of ribosomes from Escherichia coli. J Mol Biol 4, 395-406.

Strauch, E., Takano, E., Baylis, H. A. \& Bibb, M. J. (1991). The stringent response in Streptomyces coelicolor A3(2). Mol Microbiol 5, 289-298.

Takano, E. \& Bibb, M. J. (1994). The stringent response, ppGpp and antibiotic production in Streptomyces coelicolor A3(2). Actinomycetologica 8, 1-10.

Takano, E., Gramajo, H. C., Strauch, E., Andres, N., White, J. \& Bibb, M. J. (1992). Transcriptional regulation of the redD transcriptional activator gene accounts for growth-phase-dependent production of the antibiotic undecylprodigiosin in Streptomyces coelicolor A3(2). Mol Microbiol 6, 2797-2804.

Usdin, K., Gertsch, K. \& Kirby, R. (1984). Evidence for the wide distribution of repetitive DNA sequences in the genus Streptomyces. $J$ Mol Evol 20, 25-30.

Vining, L. C. (1986). Secondary metabolism. In Biotechnology, pp. 20-38. Edited by E. Rehm \& G. Reed. Weinheim: VCH.

Waksman, S. A. \& Henrici, A. T. (1943). The nomenclature and classification of the Actinomycetes. J Bacteriol 46, 337-341.

Weltner, K., Grosjean, J., Schuster, P. \& Weber, W. J. (1986). Matbematics for Engineers and Scientists. Cheltenham: Stanley Thornes.

Zyskind, J.W. \& Smith, D.W. (1992). DNA replication, the bacterial cell cycle and cell growth. Cell 69, 5-8.

Received 16 February 1996; accepted 7 March 1996 